The Difficulty of Discerning What's Too Tight:

Taylor Rules and Japanese Monetary Policy

\title{
Adam Posen
}

and

Kenneth Kuttner

Working Paper No. 218

Working Paper Series

Center on Japanese Economy and Business

Columbia Business School

February 2004 


\title{
The Difficulty of Discerning What's Too Tight: \\ Taylor Rules and Japanese Monetary Policy
}

\author{
Kenneth N. Kuttner \\ Oberlin College \\ and \\ Adam S. Posen ${ }^{*}$ \\ Institute for International Economics
}

Revised November 16, 2003

Original May 16, 2003

\begin{abstract}
Observers have relied increasingly on simple reaction functions, such as the Taylor rule, to assess the conduct of monetary policy. Applying this approach to deflationary or near-zero inflation environments is problematic, however, and this paper examines two shortcomings of particular relevance to the Japanese case of the last decade. One is the unusually high degree of uncertainty associated with potential output in an environment of prolonged stagnation and deflation. Consequently, reaction function-based assessments of Japanese monetary policy are so sensitive to the chosen gauge of potential output as to be unreliable. The second shortcoming is the neglect of policy expectations, which become critically important as nominal interest rates approach zero. Using long-term bond yields, we identify five episodes since 1996 characterized by abrupt declines in Japanese inflation expectations. Policies undertaken by the Bank of Japan during this period did little to stabilize expectations, and the August 2000 interest rate increase appears to have intensified deflationary concerns.
\end{abstract}

JEL Codes: E42, E52, F41, E31

Keywords: Deflation, Monetary Policy, Policy Rules, Taylor Rule, Japan

\footnotetext{
* Forthcoming in the North American Journal of Economics and Finance. An earlier version was resented at the CMC Lowe Institute Workshop on The Macroeconomics of Low Inflation and the Prospects for Global Deflation, April 25-26, 2003. We are grateful to Richard Jerram, Athanasios Orphanides, Frederico Ravenna, Shigenori Shiratsuka, two anonymous referees, the editor, and the workshop participants for their comments, and to Samantha Davis for her expert assistance and advice. All views expressed here and any errors are those of the authors, and not necessarily those of the Institute for International Economics. CIIE, 2003. Contact: kenneth.kuttner@,oberlin.edu or aposen@iie.com.
} 


\title{
The Difficulty of Discerning What's Too Tight: \\ Taylor Rules and Japanese Monetary Policy
}

\author{
Kenneth N. Kuttner and Adam S. Posen
}

November 16, 2003

\section{The trouble with Taylor rules in low inflation environments}

Monetary policy must be evaluated, both by those conducting the policy and by those in markets and in the political realm holding it accountable. In recent years, the academic literature as well as the financial press and pundits have relied increasingly on simple monetary policy reaction functions, such as the eponymous rule of Taylor (1993), to make that assessment. Using (seemingly) readily available data and requiring little or no estimation, an analyst using a Taylor (or similar) rule can give a simple yes or no answer to the question of whether policy at a given moment is too tight or too loose. For academics, Taylor-like reaction functions are appealing to the extent that they can be interpreted as reasonable approximations to the optimal instrument rules derived from simple, micro-founded macro models. ${ }^{1}$

As with most current forms of comfort in macroeconomics, however, Taylor rule analysis becomes problematic when confronting a low-inflation environment, and particularly when facing the experience of Japan's Great Recession. Many commentators have focused on the obvious difficulty that when the central bank's nominal instrument interest rate nears zero, it is impossible to evaluate actual policy measures by means of a Taylor rule that might suggest negative instrument interest rates. ${ }^{2}$ But this self-evident concern is misplaced in at least two ways. First, even when the instrument interest rate is zero, the same theoretical approaches that

\footnotetext{
${ }^{1}$ See Clarida, Galí, and Gertler (1999), Goodfriend and King (2001), and Giannoni and Woodford (2003) for the canonical and widely-cited examples of tractable new Keynesian/Classical models that yield Taylor rule-like reaction functions from theoretically appealing underlying assumptions.

${ }^{2}$ Taylor himself acknowledged this issue, arguing instead for money supply rules in a deflationary environment (Taylor, 1997). Nonetheless, Taylor (2001) presents an assessment of BoJ policy using a conventional Taylor rule.
} 
underlie Taylor rule analysis imply that a credible commitment to a future course of interest rates should have the same effect as a movement in the interest rate today. ${ }^{3}$ Thus, the issue for monetary policy assessment when interest rates near zero becomes how to discern whether such a commitment exists and is believed by the market and households.

Second, even if there is sufficient room left in nominal interest rates to make an assessment based on some version of a Taylor rule, uncertainty over the potential rate of growth in the economy is likely to rise as inflation approaches zero. This is both a statistical artifact, a result of the econometric methods employed to make most "top-down" estimates of potential output, and a substantive difficulty, reflecting the difficulty of distinguishing between structural change and deficient aggregate demand in times of financial distress (almost inevitably coincident with low inflation/deflationary periods). The Taylor rule assessment depends upon an estimate of potential output to such a degree that its results are extremely fragile to variation or uncertainty about this estimate, contrary to the usual blithe assumption that potential output is known with certainty.

Both of these issues played critical roles in the debate over what happened in Japan over the last decade, and particularly in the assessment of monetary policy there. In the early part of the Great Recession, from 1992 to 1998, differing assessments of the downturn's severity between various Japanese government agencies and the market, based on differing estimates of potential growth, determined the relative willingness to undertake countercyclical

\footnotetext{
${ }^{3}$ Or, to put it another way: the Taylor rule-like reaction functions are typically derived in the context of a discretionary monetary policy, while the gains from policy commitment become large when the policy rate is constrained by the zero lower bound. Absent such a commitment, Orphanides and Wieland (2000) show that it may be optimal for a central bank to ease policy more aggressively than it would have otherwise, in order to avoid hitting the zero lower bound on the nominal interest rate.
} 
macroeconomic stimulus. ${ }^{4}$ The Bank of Japan [BoJ], though lacking legal independence until April 1998, participated in these debates, and had to make its monetary policy judgments on the basis of some estimate of the output gap (or a similar measure of economic slack). From the time that the zero nominal interest rate bound was approached in early 1998, however, the BoJ was confronted by the need to undertake a policy of quantitative measures, and to consider purchases of "unconventional" assets in order to pursue its policy goals. Thus, the difficulty in assessment of monetary policy became one of whether the BoJ's actions constituted a credible commitment to a future path of interest rates, and then whether that commitment was having the desired effect.

Admittedly, Japan's descent into and then persistence of deflation is a particularly difficult case for discerning whether or not monetary policy is too tight. It is through such difficult cases, however, that the limitations of Taylor rule assessments of monetary policy are most clearly illustrated. Therefore, we have undertaken this study to demonstrate the difficulties of discerning whether monetary policy was too tight in Japan during the Great Recession, at least by utilizing the reaction function approach. ${ }^{5}$

Proceeding chronologically if not logically, we first address the difficulties presented by uncertainty over potential output in Japan. We catalog the variety of approaches undertaken by previous investigators to estimate potential output for use in Taylor rule assessments of Japanese monetary policy, and show the dispersion of findings that have resulted in the Taylor rule assessments. We then discuss the real reasons for uncertainty about Japanese potential output over this period, and trace how these account for the major divergences in ex post evaluations of

\footnotetext{
${ }^{4}$ See the discussion of demand vs. supply side interpretations of Japanese stagnation in Posen (1998, ch. 2) and the comparison of public and private economic forecasts in Ahearne, et al. (2002).
} 
BoJ monetary policy. Turning to an assessment of policy expectations, propose gauging the credibility of anti-deflationary monetary policy by looking for occurrences of "deflation scares," along the lines of Goodfriend's (1993) analysis of "inflation scares" in the U.S. Jointly examining of a chronology of the policy measures taken by the Bank of Japan and the behavior of long-term interest rates over the past several years, we conclude that the central bank's actions were ineffective at preventing declines in long-term inflation expectations.

\section{What if anything do reaction functions tell us about Japanese monetary policy in the Great Recession?}

With BoJ policy under intense scrutiny in recent years, it is no surprise that there have been many efforts to use reaction function analysis to assess its reaction to the onset of the recession early in the decade. There is little agreement among these studies, however: some find that the BoJ was too tight over this period, while others suggest its reaction was appropriate, or even that the call rate was set too low. Even those that agree that BoJ policy went from being "too loose" in the late 1980s to "too tight" in the early 1990s differ considerably as to exactly when the change took place. The variety of divergent assessments of the Japanese experience illustrates some of the pitfalls, discussed above, regarding the measurement problems inherent in the reaction function approach. In this section, we show that assumptions concerning the output gap are particularly important: both the specification for the underlying trend in potential output, and the use of real-time versus ex-post estimates in the analysis play a role. Whether assessments are made using a forward-looking specification, rather than Taylor's original backward-looking equation, also makes a big difference in the appraisal.

\footnotetext{
${ }^{5}$ The working presumption of most monetary economists is that if deflation persists, monetary policy must be too tight, because sufficient monetary ease must eventually raise the price level, and ongoing deflation is harmful to growth and financial stability. These issues are important, but beyond the scope of the present paper.
} 


\subsection{The difficulty of assessing potential growth}

Table 1 summarizes some of the best known of earlier efforts to make Taylor rule type assessments of Japanese monetary policy, distinguishing key features of the various methods used. There are two basic ways in which the method of monetary policy assessment by reaction function can be applied. In some applications, a reaction function is "calibrated" with standard parameter values, such as those proposed by Taylor (1993), and the resulting implied path of the short-term interest rate is compared with the data. Examples of this approach applied to Japan include McCallum (2000) and (2003), Taylor (2001) and Okina and Shiratsuka (2002). The alternative approach is to estimate a reaction function over the relevant sample period, and compare the estimated parameters with "reasonable" values obtained elsewhere in the literature. Bernanke and Gertler (1999) and Kuttner and Posen (2001a) are examples of this approach. Some studies, such as Jinushi et al. (2000) and Ahearne et al. (2002), apply both approaches: they estimate a reaction function over the pre-recession period, and use the empirical reaction function from that period to assess the BoJ's policy in a subsequent period.

By definition, the application of reaction functions such as the Taylor rule requires some estimate of potential output (or alternatively, the output gap), both because policymakers care about output stabilization directly and because the gap also has forecasting power for the policymakers' other postulated goal, price stability. Usually overlooked is the fact that estimates of potential output are typically associated with a great deal of uncertainty. ${ }^{6}$ An especially difficult complication in the case of Japan is how to handle the sustained decline in growth, and whether it in fact represents a true break in the trend rate of growth sometime in the early- or

\footnotetext{
${ }^{6}$ This is not the only reaction function ingredient that is subject to uncertainty, of course; another is the equilibrium or "natural" rate of interest, which may change as a result of shifts in trend GDP growth. Incorporating these additional sources of uncertainty would exacerbate the fragility problem discussed in this paper. Still, the estimate of potential output is probably open to the widest range of error, as will be seen in the various estimates we catalog
} 
mid-1990s.

By just about any measure, Japan's economy has fallen far short of its potential since 1992. To be more specific about estimating potential output for use in a Taylor rule, one has to use one of two methodologies: top-down, that is a statistical filtering method that looks at macroeconomic time-series data and filters it based on limited assumptions; or bottom-up, that is constructing a growth rate from changes in productive factors and productivity, based on assumptions about a production function and the NAIRU. The top-down methods, like the latent variable approach of Kuttner (1992) or the commonly used Hodrick-Prescott [HP] filter, require that potential output evolves smoothly over time and that actual GDP eventually reverts to potential - any sustained period of below potential growth, through the statistical assumption of a mean-reverting output gap, somewhat mechanically leads to a downward shift in the estimate of potential. Moreover using inflation movements to help gauge the output gap can be misleading in conditions of deflation where the nonlinearities created by price and wage stickiness presumably become more severe. Obviously, both of these complications are present in the Japanese situation.

The bottom-up method, like that used in the construction of the OECD's estimates and in a recent BoJ study of potential output (Bank of Japan, 2003), inevitably incorporate strong assumptions about the future growth of factor inputs and the returns to those inputs, both of which are endogenous. How should analysts looking at the Japanese situation consider the possibilities of changes in the retirement age, in the participation of women in the work force, or in the possibility of importing labor services? Should the current capital-output ratio be taken as an indicator of overinvestment in Japan or should the most recent capital investment, including

for Japan. 
in new technologies, be considered more productive than old bubble investments, raising average returns on capital? There are no easy answers to these questions. Meanwhile, deregulation in the energy, financial, retail, and telecommunations sectors in Japan, as well as limited but significant corporate restructuring, have arguably acted in the direction of raising Japanese potential output in recent years. ${ }^{7}$ Again, even without recourse to structural slump explanations of Japan's economic stagnation (e.g., Hayashi and Prescott (2000)), there is a wide range of difficulties in establishing Japanese potential output in the period.

\subsection{Alternative approaches, conflicting findings}

Table 1 summarizes along three dimensions the various methods used to construct the output gap estimates that underlie the application of reaction function analysis to the Japanese situation. (Interestingly, all of these applications use the "top-down" method.) The first dimension concerns discerning the trend itself and whether or not there has been a structural break. Approaches to this question include a simple linear trend as in Taylor (2001), the Hodrick-Prescott filter as in Okina and Shiratsuka (2002), a "kinked" trend as in McCallum (2000, 2003), and a quadratic trend as in Kuttner and Posen (2001a).

The second dimension is the choice between a "real-time" estimate of the output gap versus an "ex post" measure. As first observed by Kuttner (1992) and subsequently stressed in work by Orphanides (2001), the real-time estimate is the relevant one for a fair evaluation of monetary policy, as it reflects the information actually available to policymakers at the time. None of the studies summarized in Table 1 uses a true real time estimate of the output gap based on the unrevised data available to the BoJ at the time. But some, such as Jinushi et al. (2000), use "quasi-real-time" estimates derived from recursive estimates on revised data, thus not

\footnotetext{
${ }^{7}$ See Posen (2001) and the comments by Dickens and Hall on Kuttner and Posen (2001b) for more extensive
} 
allowing the procedure to "peek" at data later in the sample. It is quite common, however, for studies to ignore this issue, and use retrospective estimates of the output gap, such as those derived from a full-sample Hodrick-Prescott (HP) filter, or a kinked trend with a break point determined ex-post, as in Okina and Shiratsuka (2002), and McCallum (2000, 2003). Ahearne et al. (2002) employ a hybrid method, with an ex-post estimate of potential output but real-time internal Board of Governors inflation forecasts.

A third dimension along which the studies differ is on the use of a backward-looking reaction function, such as Taylor's, versus a forward-looking specification like that in Clarida Galí and Gertler (2000). This latter specification is more attractive, in that it makes the reasonable assumption that policymakers set interest rates based on their expectations of future economic developments. Also, the interpretation of the parameters in the forward-looking specification is cleaner, because the coefficient on the output gap in Taylor's backward-looking specification may capture the inflationary implications of the gap, rather than a response to output per se. The studies summarized in Table 1 differ in this dimension as well, with Taylor (2001) and McCallum (2000, 2003) using backward-looking equations, and Bernanke and Gertler (1999) and Ahearne et al. (2002) using a forward-looking model. Some use both.

Given so many differences in technique and underlying assumptions, it should come as no surprise that the assessments of BoJ monetary policy implied by these studies, summarized in Table 2, vary widely. Some conclude that policy was too tight over most of the 1980s and 1990s, while others conclude it was too loose; others find it was too tight at times and too loose at others. Still others conclude that policy did not deviate significantly from the path prescribed by the policy rule. Even studies based on a very similar methodology, such as Taylor (2001) and 
McCallum $(2000,2003)$ reach conflicting conclusions. This alone calls into question the usefulness of the reaction function approach.

\subsection{Why are reaction functions' implications so fragile?}

Having demonstrated the sensitivity of the reaction function analyses to the measurement issue problem highlighted earlier, it is clear that this, along with a few other elements of the specification, can potentially explain most of the discrepancies between the studies. To illustrate the importance of the measurement issue, we calculate a set of five consistently specified reaction functions varying only in their different measures of the output gap: three use quasi-realtime estimate, and two use retrospective measures (i.e., using ex post data from the whole sample not available at the time of monetary policy decision to generate the estimate). The first of the quasi-real-time estimates is based on a linear trend estimated recursively over a 40-quarter rolling window. The second is a one-sided implementation of the HP filter, i.e., the filter applied recursively to the data up to (but not beyond) the date at which the policy rule is calculated. ${ }^{8}$ The third is a one-sided version of the potential output model developed in Posen (1998) and Kuttner and Posen (2001b), in which inflation and output growth are used as indicators of unobserved potential output. The first of the two retrospective measures of potential output is the popular HP filter applied to the entire sample. The second is a trend with linear and quadratic terms, also applied to the whole sample.

The five estimates of the output gap, displaying great variation among them, appear in Figure 1. The key difference is between the two retrospective and the three real-time estimates: the recession, which started in 1991, tends to be sharper and deeper for the real-time versions. The reason is that retrospective measures, like the full-sample HP filter, take into account the

\footnotetext{
${ }^{8}$ The smoothing parameter is set to the conventional value of 1600 .
} 
stagnation in the 1990s in calculating their estimates of potential output in the 1980s, and so the later stagnation defines down the initial output gaps. Consequently, in the retrospective estimates, potential output growth falls off significantly well in advance of the business cycle peak in 1991. This can be seen quite clearly in Figure 2, which plots the estimated growth rate of potential output for each of the five measures. ${ }^{9}$ Not surprisingly, differences in the behavior of potential output implied by these specifications will turn out to account for a great deal of the discrepancies in the reaction functions' policy implications.

As discussed above, the calibration approach to monetary policy assessment involves a comparison between the interest rate set by the central bank with that implied by a simple policy rule. And the simplest application of this method involves inserting current inflation and an estimate of the output gap into Taylor's original equation,

$$
\tilde{\imath}_{t}=i^{*}+\alpha\left(y_{t}-y^{*}{ }_{t}\right)+\beta\left(\pi_{t}-\pi^{*}\right)
$$

using the same coefficients of 1.5 on the inflation gap, $\left(\pi_{t}-\pi^{*}\right)$, and 0.5 on the output gap, $\left(y_{t}-\right.$ $y_{t}^{*}$ ), that Taylor (1993) found fit the U.S. for the 1987-92 period. The target rate of inflation $\pi^{*}$ is assumed to be $2 \%$, and the intercept $i^{*}$ is set to 5.0 , consistent with a $3 \%$ equilibrium real rate of interest. Figure 3 depicts the policy rate target $\tilde{l}_{t}$ implied by (1) for the various output gap proxies discussed above; nothing else differs across panels. ${ }^{10}$

The wide variations between the implied target interest rate paths shown in the figure illustrate the sensitivity of the policy prescription to the output gap measure. Some of the largest

\footnotetext{
${ }^{9}$ A similar difference is observed between the growth rate of the BoJ's benchmark estimate of the output gap and that of the full-sample HP filter (Bank of Japan, 2003, p. 35).

${ }^{10}$ Figures 3 and 4 follow the convention in the literature of depicting the "target" interest rate rather than the fitted rate from an equation that also contains lagged values of the interest rate. Using lags of the realized interest rate to calculate fitted values would, by allowing the rule to depend on the BoJ's past actions, make it appear, incorrectly, as if the rule were being followed very closely. A quasi-dynamic simulation involving lags of the fitted interest rate values would be more informative, and lead to conclusions similar to those derived from comparisons involving the "target" interest rate.
} 
differences involve the discrepancies between the retrospective and real-time estimates of potential output - especially during the onset of the recession, when the real-time measures imply sharper interest rate reductions than those observed in the data. For example, over 199192, the interest rate path associated with the recursively-estimated HP filter is consistently below that of the full-sample HP filter. This is a direct consequence of the fact that using the trend growth rate derived from the full-sample HP filter starts to turn down in 1989, while trend growth from the recursive HP filter remains at (or above) $4 \%$ until early $1991 .^{11}$

A slightly more complicated application of the calibration approach involves using inflation and/or output forecasts in a reaction function, along the lines suggested by Clarida Galí, and Gertler (2000) (hereafter CGG). Figure 4 plots the implied interest rate paths using inflation forecasts in a CGG-style reaction function

$$
\tilde{l}_{t}=i^{*}+\alpha\left(y_{t}-y_{t}^{*}\right)+\beta\left(\pi_{t}^{e}-\pi^{*}\right)
$$

along with CGG's benchmark parameter estimates for the U.S in the Volcker-Greenspan period: 2.15 on inflation, 0.93 on the output gap. The measure of expected inflation $\pi_{t}^{e}$ used in the exercise is the forecast of inflation over the subsequent four quarters obtained from a regression of inflation on two lags of the output gap estimate and inflation. In this specification, the realtime estimates of the output gap imply much sharper rate reductions in the early 1990s than either of the backward-looking specifications, or even of the retrospective output gap estimates. The main explanation for this result is simply that the output gap has a higher weight in this specification than in Taylor's: both because the coefficient on the gap is larger, and because the

\footnotetext{
${ }^{11}$ Interestingly, all of these estimates of potential output, when inserted into the Taylor rule, imply a significant increase in the call rate in 1996-97. The BoJ's maintenance of the call rate at $0.5 \%$ throughout this period suggests either that none of the gap measures correspond to what the BoJ was using, or that the Bank was not mechanically following the Taylor rule's prescription. This restraint may have arisen from the BoJ's lack of independence at the time (the BoJ became independent in April 1998).
} 
gap enters implicitly by way of the inflation forecast. ${ }^{12}$ As a result, the larger real-time estimates of the output gap in the early 1990s imply sharper rate reductions.

An alternative way to assess the conduct of monetary policy is to estimate a reaction function, and compare the estimated parameters with values thought to be associated with a "reasonable" response of policy to economic conditions. Tables 3 and 4 present the results from estimating the backward-looking specification (1) and the forward-looking specification (2) for the five output gap estimates discussed above. Both specifications are modified to allow for a second-order partial adjustment mechanism in which the current call rate depends not only on the target $\tilde{l}_{t}$ but also on two lags of the interest rate,

$$
i_{t}=\left(1-\rho_{1}-\rho_{2}\right) \tilde{l}_{t}+\rho_{1} i_{t-1}+\rho_{2} i_{t-2}+e_{t}
$$

resulting an estimating equation of the form

$$
i_{t}=\left(1-\rho_{1}-\rho_{2}\right)\left[i^{*}+\alpha\left(y_{t}-y_{t}^{*}\right)+\beta\left(\pi_{t}-\pi^{*}\right)\right]+\rho_{1} i_{t-1}+\rho_{2} i_{t-2}+e_{t}
$$

for the backward-looking specification, which is estimable by nonlinear least squares. The forward-looking specification replaces $\pi_{t}$ with $\pi_{t}^{e}$, and estimation is by GMM using lags of inflation, the output gap, and the call rate as instruments.

As shown in Table 3, the estimates obtained from the backward-looking specification are quite sensitive to the choice of output gap measure. Although all the estimates are "reasonable," in the sense of having the correct sign and approximately the right magnitude, they vary a great deal and they are very imprecisely estimated. The "Taylor Principle" (i.e., $\beta>1$ ) appears not to hold in two cases, but because the output gap term may to some extent capture future inflationary pressures, such an interpretation may not be entirely warranted. By contrast, the forwardlooking specification consistently yields large, significant estimates of $\beta$, regardless of which

\footnotetext{
${ }^{12}$ The larger output gap coefficient alone does not account for this result: the conclusion is similar (though less
} 
potential output proxy is used; as shown in Table 4, all are near 2.0. Furthermore, the estimates of the coefficient on the output gap, $\alpha$, are uniformly small and insignificant. Thus, the one conclusion that seems to be robust to choice of output gap proxy is that from 1986 through 2001, Japanese monetary policy tended to react strongly to inflation, but very weakly to the output gap. $^{13}$

In general, the results summarized above parallel those of Kozicki (2000), who demonstrated the non-robustness of simple reaction functions' policy implications in the case of the U.S. Conclusions drawn from real-time potential output proxies clearly represent a fairer appraisal of policy than those based on ex post estimates. But absent a convincing demonstration that one particular output gap estimate is superior to the rest, this sort of non-robustness is surely a generic feature of reaction function-based policy appraisals. ${ }^{14}$ Even so, it is sometimes argued that reaction functions, such as the Taylor rule, can at least be helpful in communicating policymakers' intentions, and providing a benchmark for the current policy stance. But even this use of Taylor-style reaction functions is problematic in the case of Japan, where the zero lower bound on nominal interest rates shifts the emphasis of policy from the current interest rate to the expected trajectory of interest rates in the future. This limitation of the Taylor rule is the topic of the next section.

\footnotetext{
dramatic) with $\alpha=0.5$.

${ }^{13}$ The lack of a measured response to the output gap could be due in part to the zero bound on the interest rate. Given this constraint, a tobit equation would be a more appropriate specification for modeling the short-term interest rate.

${ }^{14}$ Another critique of the reaction function approach to policy assessment is that it is hard to gauge the optimality of the coefficients. A fully-specified macro model would in principle provide a more rigorous way of interpreting the reaction function coefficients. But this approach would not solve the underlying problem associated with the estimation of potential output; if anything, the measurement problems would compounded by the need to estimate (or calibrate) the model's deep structural parameters.
} 


\section{Assessing the stance of expected policy}

As noted above, a deep problem with reaction function analysis is that in it, the stance of monetary policy is linked exclusively to the current setting of the short-term nominal interest rate. This approach neglects the potentially important impact of the expected future setting of monetary policy. That impact is especially important in situations where the current short-term nominal interest rate is constrained, as it is in Japan by the zero lower bound, leaving expectations of future policy as a major (if not the only) instrument of monetary policy. ${ }^{15}$ The potentially central role of expectations has been stressed both in much of the commentary on Japan, such as Krugman (1998) and Blanchard (2000), as well as in recent theoretical research, such as Eggertsson (2003) and Eggertsson and Woodford (2003).

Our assessment of monetary policy by examining expectations in Japan proceeds initially on two independent but ultimately complementary tracks. First, we examine the BoJ's announced policy actions since the mid-1990s (i.e., since approaching the zero bound on the short-term nominal interest rate) in an effort to characterize the implications of these announcements for expectations of future policy. Given the zero bound, and what it implies for the constraint on the BoJ's instruments but not on its goals, it is necessary to identify when the BoJ was affecting expectations without changing short-term rates. Second, we attempt to discern from the behavior of long-term interest rates periods in which there appears to have been a significant reduction in inflation expectations. We bring together these two strands to determine what policy actions (or alternatively inactions in the face of weakening economic conditions) might have generated the observed response of long-term interest rates, and thereby look for

\footnotetext{
${ }^{15}$ Other instruments available to the Bank of Japan might include switching the relative shares of different asset classes (or maturities of government debt), direct effects of quantitative easing, and the monetization of fiscal policy, though opinions differ on the efficacy of such instruments. There are also, however, those who dismiss the importance of expectations in the absence of a restoration of growth (e.g., Friedman (2003)).
} 
what we term "deflation scares," following Goodfriend (1993).

\subsection{Identifying "deflation scares"}

In light of the potentially important impact of policy expectations, and the fragility of the reaction function approach, there is clearly a need to develop a more forward-looking assessment of policy, and one which is less susceptible to measurement and estimation error. One way to do this is to glean information from the financial markets regarding the perceived impact of monetary policy.

Goodfriend (1993) provides one example of how this might be done. The idea is to use movements in long-term interest rates to discern changes in inflation expectations unrelated to overt monetary policy actions. Goodfriend's analysis focused on "inflation scares." These are episodes in which monetary policy was perceived as too loose, relative to mounting inflationary pressures, resulting in a widening yield spread. In the recent Japanese context, the thing to do is turn Goodfriend's analysis on its head, and focus instead on "deflation scares" (or, more accurately, "disinflation scares"). These would correspond to periods in which monetary policy was viewed as too tight to prevent further disinflation, or outright deflation, a symptom of which would be a narrowing yield curve.

Cleanly extracting changes in inflation expectations from the yield curve is problematic, however, for the simple reason that the impact of monetary policy on long-term interest rates is ambiguous. For example, an increase in short-term interest rates will tend to increase long-term interest rates by increasing near-term expectations of future short-term interest rates. But the rate hike will presumably also decrease inflation expectations; long-term interest rates may therefore fall if this effect dominates the effect on near-term short-term interest rates.

Goodfriend's solution to this ambiguity is to look only at periods where long-term 
interest rates rose in an environment of steady or falling short-term interest rates. In this case, the change in long-term interest rates would presumably be driven either by inflation expectations, or by expectations of an impending rate increase. Using a narrative approach, Goodfriend is able to distinguish between these two possibilities. The analysis undertaken here is simply a mirror image of Goodfriend's: the goal is to identify periods of falling JGB rates occurring in an environment of a steady or rising call rate. Any such change would presumably be driven either by a drop in expected inflation (a "deflation scare"), or lower near-term expectations of short-term interest rates. Note that this is a statistically driven process, identifying scares independently of the "narrative" events identified by historical analysis.

\subsection{Japanese monetary policy actions after the call rate approached zero ${ }^{16}$}

How can one discern monetary policy movements as a baseline of potential shocks to inflation expectations when the zero lower bound is reached? When the BoJ's uncollateralized overnight call rate remained at a distance from the zero nominal lower-bound, at least the assessment of its stance by Taylor rule-type approaches had a place to start. The call rate, however, remained unchanged around 0.50\% from September 1995 until September 1998 This period included recovery through fiscal year 1996, onset of recession in summer 1997, domestic financial breakdowns in autumn 1997, and the effects of the Asian financial crisis of 1997-1998, all of which might reasonably have been expected to prompt changes in monetary policy had an interest rate instrument (and transmission mechanism) been readily available. ${ }^{17}$ While the BoJ did provide several emergency injections of liquidity to the banking system during this period, but it did not announce or resort to any sustained quantitative or unconventional monetary policy

\footnotetext{
${ }^{16}$ Samantha Davis provided critical research assistance for the timeline in this section.

${ }^{17}$ The Bank's lack of legal independence until April 1998 may have played a role in this stability of the instrument interest rate.
} 
measures, nor did it indicate any changes in monetary policy stance. As the VAR literature on identifying the effects of monetary policy reminds us, though, an unchanging stance in the face of changing economic conditions may well signal changes in policy and inflation expectations.

From September 1998, however, the independent BoJ and its new Policy Board did undertake a series of measures, both to change the stance of policy and to expand the range of instruments/quantitative measures available to it, in response to economic developments (see Table 5). ${ }^{18}$ At a minimum, we need to know what was attempted to see whether it had any (intended) effect, even in the absence of ability to simply insert it into a Taylor rule. On the interest rate side, the overnight call rate was reduced in two steps from $0.50 \%$ to $0.15 \%$, raised to $0.25 \%$ in August 2000 , and then lowered again in two steps to $0.10 \%$ between February and September 2001. The Bank also created a "Lombard-like" lending facility, and lowered the discount rate in order to stimulate use of that facility, reaching $0.10 \%$ in September 2001 as well. Given the ongoing price deflation of this period, implying a need for infeasible negative nominal interest rates, however, there is no real way to fairly assess such movements on their own terms by means of a Taylor rule estimate.

The BoJ also undertook several quantitative monetary (as opposed to financial stabilization) measures over this period. An ever-broadening range of commercial paper types, eventually to include asset- and mortgage-backed securities, were made eligible for repo operations. Similarly, a wider range of government securities, ultimately encompassing shortterm bills and loans to the government, were made eligible for the Bank's operations. In March 2001, the Policy Board made the current account balances of banks at the BoJ the primary target of policy, rather than the then at effective bottom call rate; in February 2002, the Bank

\footnotetext{
${ }^{18}$ This timeline of BoJ policy was compiled from public releases listed on the Bank's website.
} 
committed to providing liquidity in excess of that target. Monthly outright purchases of Japanese government bonds more than tripled to 1.2 trillion yen by October 2002 .

Assessing the content of these moves was made more difficult by repeated references by Policy Board members to the likely ineffectiveness of "quantitative measures."19 The broadening of assets available to the Bank to purchase, as a start on "unconventional measures" was even more unclear in its implications. In the first place, if such changes in asset purchases did not change the overall infusion of liquidity into the economy, whether or not these would be in fact expansionary was in question. ${ }^{20}$ In the second place, these measures were explicitly questioned by those undertaking them. ${ }^{21}$

The question relevant to our investigation, therefore, is whether the BoJ policy measures taken during this period were perceived as contributing expansionary monetary policy. Specifically, one would want to know whether the interest rate, quantitative measures, and broadening of assets available for open market operations, undertaken by the BoJ over this period perceived as committing the Bank to (or at least signaling) future policy interventions of a sort that would be expected to reduce deflationary pressures.

Three instances merit special scrutiny, occasions on which there seems to have been an explicit intention to affect expectations about future interest rates. ${ }^{22}$ In a Policy Board meeting on April 9, 1999, Governor Hayami and other senior officials turned the call rate cut of February 12, 1999 into the "Zero Interest Rate Policy" [ZIRP]. They clarified this in a series of speeches

\footnotetext{
${ }^{19}$ See the references in Kuttner and Posen (2001b) and Posen (2003).

${ }^{20}$ The announcement of the purchase of equities from banks by the BoJ on September 19, 2002, for example, prompted an auction undersubscription for JGBs the next day because remarks by the Policy Board were interpreted to mean that fewer JGBs would be bought as stocks were purchased.

${ }^{21}$ See the statements by Governor Yukata Yamaguchi, July 3, 2002, (http://www.boj.or.jp/en/press/02/ko0207b.htm), and by BoJ Policy Board Member Teizo Taya, December 20, 2002, (http://www.boj.or.jp/en/press/02/ko0212b.htm, to cite two notable examples.

${ }^{22}$ These announcement are designated on Table 3 by the use of bold italics.
} 
over the summer, but the key point was made in the minutes of the April $9^{\text {th }}$ meeting, released a month later: "it was important to maintain the current decisive easy stance of monetary policy, firmly underpinning economic activity until deflationary concerns were dispelled.” This appeared to commit the Bank to a long-term path of ease. On August 11, 2000, however, the Bank raised the call rate to $0.25 \%$, in contradiction of this commitment (and in direct contravention of the Ministry of Finance's request to postpone the interest rate vote), citing "the improvement of the economy" without direct reference to deflation. Finally, on March 19, 2001, following a reversal of the rate increase, the Policy Board announced that there was a new monetary policy strategy that included a commitment that "The new procedure will be kept in place until the CPI registers a stable zero percent or increase year on year and should affect people's expectations in order to help reduce the deflationary bias."

\subsection{Six years of deflation scares}

Figure 5 shows the average overnight call money rate and month-end JBG yield from January 1992 to the present (March 2003). Up until 1995, all of the major declines in long-term interest rates were accompanied by cuts in the overnight rate. But beginning in 1996, five distinct "deflation scare" episodes are evident in the data, as highlighted by the shaded areas on the figure: August to November 1996, June to October 1997, February to May 1998, September 2000 to February 2001, and March 2002 to the present. ${ }^{23}$

The first three deflation scares take place during the period in which the BoJ's call rate was not moved from $0.50 \%$, and also no new quantitative expansion efforts or broadening of assets for purchase (except in financial emergencies) were undertaken. The June to October

\footnotetext{
${ }^{23}$ Formally, three conditions define the onset of a "deflation scare": (1) a fall in the current long-term bond yield, (2) non-increasing bond yields in the subsequent three months, and (3) no reductions in the call money rate. The
} 
1997 and February to May 1998 scares can be cleanly associated with negative economic shocks (developments in the Asian financial crisis, and in the latter case in the Japanese financial system as well) that would have moved general economic expectations downwards, while the BoJ took no policy action (during the November 1997 to January 1998 interregnum, the BoJ was involved in direct financial stabilization measures which may have given the appearance of stabilizing the situation and/or being in part monetary expansion). The August to November 1996 deflation scare is difficult to associate with any cause, given that it took place during a period of economic recovery, with most observers seeing surprises on the upside for inflation and growth. Of course, the September 2000 to February 2001 deflation scare fits perfectly with the period between the August 11, 2000 increase in the BoJ's call rate and the February 28, 2001 reversal of that increase - the lifting of the ZIRP was seen as deflationary by the markets, as would have been expected by most monetary economists, especially since (as noted above) it seemed to invalidate a commitment to a future path of looser policy.

The most recent deflation scare in the sample, from March 2002 to the end of the sample a year later, deserves special note, as it is the only such episode to have occurred during the BoJ's zero interest rate policy, as well as the scare being sustained for the longest period. The straightforward interpretation is that well-documented and publicized weaknesses in the Japanese banking system, revealed at fiscal year-end 2001, increased the perceived likelihood of a debtdeflation spiral, and the BoJ's quantitative measures were discounted as a response. ${ }^{24}$

It is instructive to compare this interpretation with that of Okina and Shiratsuka (2003), who characterize the episode as one in which the expected duration of the prevailing zero interest

\footnotetext{
"scare" ends when there is either (1) a greater-than five basis point increase in the bond yield, or (2) a reduction in the call money rate.

${ }^{24}$ See Posen $(2002,2003)$ for discussions of this period and the apparent evidence for incipient debt-deflation.
} 
rate policy was increasing, while the expected overall level of interest rates in the distant future was falling. Thus, the BoJ's stated policy of maintaining a zero interest rate "until deflationary pressures have subsided" means that as the economy weakened, the date of any future interest rate increases was deferred, and this accounts for the observed fall in long-term interest rates.

Although this might appear to contradict the episode's designation as a "deflation scare," the two interpretations are in fact consistent. The reason is that the appropriate policy response to weakening economic conditions would be a further reduction in the real interest rate; with the short-term interest rate constrained at zero, the only way to do this is to increase inflation expectations. ${ }^{25}$ Thus, a policy that, in the face of intensifying deflationary pressure, commits only to bring the inflation rate back up to zero, is insufficiently expansionary - particularly against a backdrop of falling asset prices, banking system distress, and a fiscal situation often characterized by government officials as unsustainable. This interpretation is corroborated by Okina and Shiratsuka's (2003) finding that long-horizon expectations of the short-term nominal interest rate also fell over this period.

\section{Conclusions - what Taylor rules do and do not tell us about Japan}

We have considered two issues regarding the applicability and informativeness of Taylor rules as a means of monetary policy assessment in the low-inflation environment of Japan's Great Recesssion. First, we addressed the difficulties presented by uncertainty over potential output in Japan. A wide variety of approaches were undertaken by previous investigators to estimate potential output for use in Taylor rule assessments of Japanese monetary policy, and these have resulted in a wide spread of assessments, as we document. Given the real (substantive

\footnotetext{
${ }^{25}$ This idea has been elegantly formalized in a recent paper by Eggertsson and Woodford (2003). In their model, the optimal policy rule is related to a price level target, and requires a commitment to a higher level of future inflation (or at least a longer period of above-target inflation) the longer the nominal interest rate remains constrained. Such a
} 
and statistical) reasons for uncertainty about Japanese potential output over this period, and we argue that these account for the major divergences in ex post evaluations of BoJ monetary policy. Our conclusion is that while one can argue that there is a preferable means of estimating potential output for this purpose, ${ }^{26}$ that argument is hardly settled, and even after picking any one method there remains great uncertainty, sufficient to render the Taylor rule assessments of Japanese monetary policy unreliable.

We then considered the communication of future commitments about the course of interest rates through the BoJ's quantitative and unconventional measures since the nominal interest rate neared zero. Our assessment of the impact of developments in the current stance and approach of Japanese monetary policy on expectations begins with a timeline of those developments drawn up from official releases by the Bank of Japan. We find that deflation scares have occurred in Japan five times since 1996, notably prompted by an interest rate increase in August 2000 that reversed a commitment to a future "zero-interest rate policy" until deflationary concerns would be dispelled, and one that persisted through much of 2002 seemingly associated with the BoJ's public pronouncements regarding deflation and the inefficacy of monetary policy. Consistent with the evidence in Kuttner and Posen (2001b), and some $a$ priori arguments made by the BoJ, we find no evidence that the various quantitative measures and expansions of eligible assets for open market operations undertaken by the BoJ over this period had an impact on long-term bond yields. The reason, presumably, is that these measures are not expected to have a significant impact either on the future path of the policy rate, or on inflation.

policy rule is said to be "history dependent."

${ }^{26}$ One method particularly well-suited to this sort of application is that of Kuttner (1994), applied with modifications to Japan in Posen (1998) and Kuttner and Posen (2001b). 
Taking ex post Taylor rule evaluation of monetary policy at face value of course ignores a vast range of issues in the monetary policy challenge in Japan at present - a partial list would also include the asymmetries of deflation versus low inflation, the transmission mechanism breakdowns in the financial system, the economic and political interactions between monetary policy and financial reform, and the external effects and constraints of any exchange rate movements for the yen. It also ignores broader normative approaches to evaluating the welfare of any given monetary policy. In a sense, this is precisely the point of this paper: that monetary policy evaluation cannot be done by rote rules any more than policymaking can. 


\section{References}

Ahearne, Alan, Joseph Gagnon, Jane Haltimaier, and Steve Kamin (2002). "Preventing Deflation: Lessons from Japan's Experience in the 1990s," Board of Governors of the Federal Reserve System, International Finance Discussion Paper \#729, June.

Bank of Japan (2003), "The Output Gap and the Potential Growth Rate: Issues and Applications as an Indicator for the Pressure on Price Change," Quarterly Bulletin, May, pp. 1-41.

Bernanke, Ben S. and Mark Gertler (1999). "Monetary Policy and Asset Price Volatility," Federal Reserve Bank of Kansas City Economic Review, $4^{\text {th }}$ Quarter.

Blanchard, Olivier (2000). "Bubbles, Liquidity Traps, and Monetary Policy." In Japan's Financial Crisis and Its Parallels to U.S. Experience, edited by Ryoichi Mikitani and Adam S. Posen. Washington: Institute for International Economics.

Calderwood, Chris and Mikihiro Matsuoka (2000). "The Inflation-loving BoJ,” Jardine Fleming Research, 29 August.

Clarida, Richard, Jordi Galí, and Mark Gertler (1999). “The Science of Monetary Policy: A New Keynesian Perspective," Journal of Economic Literature 37 (December), pp. 1661-1707.

Clarida, Richard, Jordi Galí, and Mark Gertler (2000). "Monetary Policy Rules and Macroeconomic Stability: Evidence and Some Theory," Quarterly Journal of Economics 115 (February), pp. 148-80.

Eggertsson, Gauti (2003). "Fighting Deflation at Zero Nominal Interest Rates: Committing to Being Irresponsible," IMF Working Paper, forthcoming.

Eggertsson, Gauti and Michael Woodford (2003). "The Zero Bound on Interest Rates and Optimal Monetary Policy," Brookings Papers on Economic Activity, forthcoming.

Finan, Frederico, Athanasios Orphanides, Richard D. Porter, David Reifschneider and Robert Tetlow (1999). "Errors in the Measurement of the Output Gap and the Design of Monetary Policy," Federal Reserve Board Finance and Economic Discussion Series, 1999-45.

Friedman, Benjamin (2003). "Discussion of "The Zero Bound on Interest Rates and Optimal Monetary Policy," Brookings Papers on Economic Activity, forthcoming.

Giannoni, Marc P. and Michael Woodford (2003). "Optimal Interest-Rate Rules: I. General Theory," NBER Working Paper 9419, January.

Goodfriend, Marvin (1993). "Interest Rate Policy and the Inflation Scare Problem: 1979-1992," Federal Reserve Bank of Richmond Economic Quarterly 79 (Winter), pp. 1-23. 
Goodfriend, Marvin and Robert G. King (2001). "The Case for Price Stability," NBER Working Paper No. 8423, August.

Hayashi, Fumio and Edward C. Prescott (2000). "The 1990's in Japan: A Lost Decade," Minneapolis Federal Reserve Working Paper 607, November.

Jerram, Richard (1998). “Inflation Targeting,” ING Barings Japan Economics, December.

Jinushi, Toshiki, Yoshihiro Kuroki, and Ryuzo Miyao (2000). "Monetary Policy in Japan Since the Late 1980s: Delayed Policy Actions and Some Explanations," in Mikitani and Posen (eds.), Japan's Financial Crisis and Its Parallels to U.S. Experience. Washington D.C.: Institute for International Economics.

Kozicki, Sharon (1999). "How Useful are Taylor Rules for Monetary Policy?" Federal Reserve Bank of Kansas City Economic Review, second quarter, 5-33.

Krugman, Paul R (1998). "It's Baaack: Japan's Slump and the Return of the Liquidity Trap." $B P E A, 2: 1998,137-205$.

Kuttner, Kenneth N. (1992). "Monetary Policy with Uncertain Estimates of Potential Output," Federal Reserve Bank of Chicago Economic Perspectives 16 (Jan./Feb.), pp. 2-16.

Kuttner, Kenneth N. and Adam S. Posen (2001a). "Inflation, monetary transparency, and G3 exchange rate volatility," in Balling, Hochreiter and Hennessy (eds), Adapting to Financial Globalisation, pp. 229-258. London: Routledge.

Kuttner, Kenneth N. and Adam S. Posen (2001b). "The Great Recession: Lessons for Macroeconomic Policy from Japan,” BPEA, 2:2001, 93-198.

McCallum, Bennett T. (2003). “Japanese Monetary Policy, 1991-2001," Federal Reserve Bank of Richmond Economic Quarterly 89 (Winter) pp. 1-31.

McCallum, Bennett T. (2000). "Alternative Monetary Policy Rules: A Comparison with Historical Settings for the United States, the United Kingdom, and Japan," Federal Reserve Bank of Richmond Economic Quarterly 86 (Winter), pp. 49-79.

Mikitani, Ryoichi and Adam S. Posen (2000). Japan's Financial Crisis and Its Parallels to US Experience, Special Report 13, Washington: IIE, September.

Okina, Kunio and Shigenori Shiratsuka (2003). "Policy Commitment and Expectation Formations: Japan's Experience under Zero Interest Rates.” Mimeo, Bank of Japan.

Okina, Kunio and Shigenori Shiratsuka (2002). "Asset Price Bubbles, Price Stability, and Monetary Policy: Japan's Experience.” Bank of Japan Monetary and Economic Studies, October, pp. 35-76.

Orphanides, Athanasios (2001). "Monetary Policy Rules Based on Real-Time Data," American Economic Review 91, pp. 964-85. 
Orphanides, Athanasios and Volcker Wieland (2000). "Efficient Monetary Policy Design Near Price Stability," Journal of the Japanese and International Economies 14, pp. 327-365.

Posen, Adam S. (2003). "Japanese Macroeconomic Policy: Unusual?" mimeo, Institute for International Economics, November.

Posen, Adam S. (2002). “The Looming Japanese Crisis,” IIE Policy Brief 02-5, May.

Posen, Adam S. (2001). "Recognizing Japan's Rising Potential Growth," NIRA Review, Volume 8, Number 1, Winter, pp. 48-53.

Posen, Adam S. (1998). Restoring Japan's Economic Growth. Washington: Institute for International Economics.

Taylor, John B. (1993). "Discretion versus Policy Rules in Practice," Carnegie-Rochester Conference Series on Public Policy 39, pp. 195-214.

Taylor, John B. (1997). "Policy rules as a means to monetary policy," in Kuroda (ed.), Towards More Effective Monetary Policy, St. Martin's Press, New York.

Taylor, John B. (2001). "Low Inflation, Deflation, and Policies for Future Price Stability," Bank of Japan Monetary and Economic Studies 19, pp. 35-51.

Tetlow, Robert J. and Peter von zur Muehlen (1999). "Simplicity Versus Optimality: The Choice of Monetary Policy Rules When Agents Must Learn," Federal Reserve Board Finance and Economic Discussion Series, 1999-10. 
Table 1

Summary of Reaction Function Analysis

\begin{tabular}{|c|c|c|c|c|c|c|c|}
\hline & Gap measure & $\begin{array}{l}\text { Real-time/ } \\
\text { ex-post }\end{array}$ & $\begin{array}{l}\text { Forward/ } \\
\text { backward }\end{array}$ & $\begin{array}{l}\text { Estimated/ } \\
\text { calibrated }\end{array}$ & Estimation sample & $\begin{array}{c}\text { Inflation } \\
\text { coefficient }\end{array}$ & $\begin{array}{l}\text { Output } \\
\text { coefficient }\end{array}$ \\
\hline Bernanke/Gertler (1999) & $\begin{array}{l}\text { IP, deviation from } \\
\text { quadratic trend }^{\mathrm{a}}\end{array}$ & Real-time & Forward & Estimated & $\begin{array}{l}\text { 1989:7-1997:12, } \\
\text { monthly }\end{array}$ & $1.12^{*}$ & $0.30^{*}$ \\
\hline Ahearne et al. (2002) & GDP, staff estimate & ex-post & Forward & Estimated & $\begin{array}{l}\text { 1981Q1-2001Q3, } \\
\text { quarterly }\end{array}$ & $2.31^{*}$ & 0.05 \\
\hline Kuttner/Posen (2001) & $\begin{array}{l}\text { IP, deviation from } \\
\text { broken trend }\end{array}$ & ex-post & Both & Estimated & $\begin{array}{l}\text { 1987:5-1999:12, } \\
\text { monthly }\end{array}$ & 2.97 & -0.19 \\
\hline Jinushi et al. (2000) & $\begin{array}{l}\text { GDP, deviation from } \\
\text { quadratic trend }\end{array}$ & Real-time & Both & Estimated & $\begin{array}{l}\text { 1975Q1-1985Q4, } \\
\text { quarterly }\end{array}$ & 0.40 & 1.44 \\
\hline $\begin{array}{l}\text { Calderwood/ } \\
\text { Matsuoka (2000) }\end{array}$ & $\begin{array}{l}\text { GDP, method } \\
\text { unspecified }\end{array}$ & ex-post & Backward & Estimated & $\begin{array}{l}\text { 1975Q1-1985Q3, } \\
\text { quarterly }\end{array}$ & 0.75 & 2.48 \\
\hline Okina/Shiratsuka (2002) & $\begin{array}{l}\text { GDP, HP filter cyclical } \\
\text { component }\end{array}$ & ex-post & Both & Calibrated & & & \\
\hline McCallum (2000), (2003) & GDP, broken trend & ex-post & Backward & Calibrated & & & \\
\hline Taylor (2001) & GDP, linear trend & unspecified & Backward & Calibrated & & & \\
\hline Jerram (1998) & $\begin{array}{l}\text { GDP, method } \\
\text { unspecified }\end{array}$ & unspecified & Backward & Calibrated & & & \\
\hline
\end{tabular}

Notes: Asterisks denote statistical significance at the conventional (0.05) level. For those studies that estimated both forward- and backward-looking reaction functions, the coefficients from the forward-looking equations are displayed. (a) Estimated through 1986, projected thereafter. 
Table 2

Summary of Policy Appraisals from Reaction Function Analysis

Bernanke/Gertler (1999)

Ahearne et al. (2002)

Kuttner/Posen (2001)

Jinushi et al. (2000)

Calderwood/

Matsuoka (2000)

Okina/Shiratsuka (2002)

McCallum (2000)

McCallum (2003)

Taylor (2001)

Jerram (1998)
1988-1990, too loose; 1992-1996, too tight.

Using real-time inflation forecasts, BoJ response was in line with estimated reaction function.

No comparison of actual versus prescribed policy.

1987-1991, too loose; 1992-1996, too tight.

1989-1993, too loose; 1994-1996, too tight.

BoJ response in line with backward-looking reaction function throughout; slow to react relative to "perfect foresight" forward-looking reaction function.

1982-87, "slightly too tight"; 1987-1994, "about right."

Consistently too tight from 1982 to 1991, about right in 1992, and too tight again from 1993 to 1999.

Call rate is uniformly below target from 1988 to 1994.

1989-1991, too loose; 1991-1994, about right; 1994-1996, too tight. 


\section{Table 3}

Estimates of Backward-Looking Reaction Functions for Alternative Estimates of the Output Gap

\begin{tabular}{lccccc}
\hline & \multicolumn{5}{c}{ Parameter estimates } \\
\cline { 2 - 6 } Output gap & $r^{*}$ & $\mathrm{~B}$ & $\alpha$ & $\rho_{1}$ & $\rho_{2}$ \\
\hline Recursive & 2.36 & 1.12 & 0.58 & 1.15 & -0.29 \\
linear trend & $(0.55)$ & $(0.33)$ & $(0.17)$ & $(0.26)$ & $(0.21)$ \\
Recursive & 1.18 & 1.64 & 0.79 & 1.26 & -0.36 \\
HP filter & $(0.90)$ & $(0.49)$ & $(0.30)$ & $(0.27)$ & $(0.22)$ \\
& & & & & \\
1-sided Kuttner- & 1.88 & 0.72 & 1.60 & 1.25 & -0.34 \\
Posen model & $(0.82)$ & $(0.48)$ & $(0.64)$ & $(0.25)$ & $(0.21)$ \\
Full-sample & 0.79 & 1.11 & 0.48 & 1.36 & -0.43 \\
HP filter & $(0.65)$ & $(0.59)$ & $(0.47)$ & $(0.28)$ & $(0.25)$ \\
Quadratic trend & 0.87 & 0.60 & 0.57 & 1.38 & -0.44 \\
& $(0.96)$ & $(0.64)$ & $(0.73)$ & $(0.27)$ & $(0.25)$ \\
\hline
\end{tabular}

Notes: sample period is 1986Q1 through 2001Q1. The results are based on an equation of the form $i_{t}=\left(1-\rho_{1}-\right.$ $\left.\rho_{2}\right)\left[r^{*}+(1-\beta) \pi^{*}+\beta \pi_{t}+\alpha\left(y_{t}-y_{t}^{*}\right)\right]+\rho_{1} r_{t-1}+\rho_{2} r_{t-2}$, where $i_{t}$ is the call money rate, $\pi_{t}$ is CPI inflation (adjusted for changes in the consumption tax) over the preceding four quarters, and $y_{t}-y_{t}^{*}$ is an estimate of the output gap. For the purpose of estimating the equilibrium real rate of interest, $r^{*}$, the desired inflation rate, $\pi^{*}$ is set to 1.0 . The equation is estimated using OLS. Parentheses contain standard errors, corrected for third-order serial correlation. 


\section{Table 4}

Estimates of Forward-Looking Reaction Functions for Alternative Estimates of the Output Gap

\begin{tabular}{lccccc}
\hline & \multicolumn{5}{c}{ Parameter estimates } \\
\cline { 2 - 6 } Output gap & $r^{*}$ & $\mathrm{~B}$ & $\alpha$ & $\rho_{1}$ & $\rho_{2}$ \\
\hline Recursive & 2.14 & 2.52 & -0.04 & 1.31 & -0.45 \\
linear trend & $(0.20)$ & $(0.36)$ & $(0.21)$ & $(0.34)$ & $(0.33)$ \\
Recursive & 2.34 & 2.46 & -0.10 & 1.27 & -0.42 \\
HP filter & $(0.35)$ & $(0.32)$ & $(0.22)$ & $(0.27)$ & $(0.26)$ \\
1-sided Kuttner- & 2.10 & 1.91 & 0.51 & 1.26 & -0.37 \\
Posen model & $(0.27)$ & $(1.37)$ & $(1.34)$ & $(0.23)$ & $(0.22)$ \\
Full-sample & 1.67 & 2.79 & -0.35 & 1.27 & -0.42 \\
HP filter & $(1.26)$ & $(0.46)$ & $(0.17)$ & $(0.26)$ & $(0.26)$ \\
Quadratic trend & 1.95 & 1.93 & 0.01 & 1.49 & -0.59 \\
& $(0.31)$ & $(0.59)$ & $(0.12)$ & $(0.36)$ & $(0.33)$ \\
\hline
\end{tabular}

Notes: sample period is 1986Q1 through 2001Q1. The results are based on an equation of the form $r_{t}=\left(1-\rho_{1}-\right.$ $\left.\rho_{2}\right)\left[r^{*}+(1-\beta) \pi^{*}+\beta \pi_{t+4}+\alpha\left(y_{t}-y_{t}^{*}\right)\right]+\rho_{1} r_{t-1}+\rho_{2} r_{t-2}$, where $r_{t}$ is the call money rate, $\pi_{t+4}$ is CPI inflation (adjusted for changes in the consumption tax) over the next four quarters, and $y_{t}-y_{t}^{*}$ is an estimate of the output gap. For the purpose of estimating the equilibrium real rate of interest, $r^{*}$, the desired inflation rate, $\pi^{*}$ is set to 1.0 . The equation is estimated using GMM, using two lags of inflation, two lags of the output gap, and the lagged call rate as instruments. Parentheses contain standard errors, corrected for third-order serial correlation. 


\section{Table 5}

Monetary Policy Developments in Japan Since Approaching the Zero Nominal-Interest Bound

Events in bold italic signify explicit efforts to affect expectations about future policy

\begin{tabular}{|c|c|c|c|}
\hline Date & Development & $\begin{array}{l}\text { Change stance? } \\
\text { (Quantity/Rate) }\end{array}$ & $\begin{array}{l}\text { Change assets } \\
\text { purchased? }\end{array}$ \\
\hline $\begin{array}{l}\text { September 9, } \\
1998\end{array}$ & Reduced call rate to $0.25 \%$ & Yes & \\
\hline $\begin{array}{l}\text { November 13, } \\
1998\end{array}$ & $\begin{array}{l}\text { Expanded size and scope of } \mathrm{CP} \text { repo } \\
\text { operations }\end{array}$ & Yes & Yes \\
\hline $\begin{array}{l}\text { November 27, } \\
1998\end{array}$ & $\begin{array}{l}\text { Established "temporary lending facility" to } \\
\text { support financial firms }\end{array}$ & & Yes \\
\hline $\begin{array}{l}\text { February 12, } \\
1999\end{array}$ & Reduced call rate to $0.15 \%$; Initiated ZIRP a & Yes & \\
\hline May 18, 1999 & $\begin{array}{l}\text { Released minutes of April 9, } 1999 \text { Monetary } \\
\text { Policy Meeting announcing decision "it was } \\
\text { important to maintain the current decisive } \\
\text { easy stance of monetary policy, firmly } \\
\text { underpinning economic activity until } \\
\text { deflationary concerns were dispelled." b }\end{array}$ & & \\
\hline October 13, 1999 & $\begin{array}{l}\text { Introduced outright operations using short- } \\
\text { term government securities, expanded range of } \\
\text { government securities for repos }\end{array}$ & & Yes \\
\hline August 11, 2000 & $\begin{array}{l}\text { Raised call rate to } 0.25 \% \text {, contradicting ZIRP } \\
\text { in light of government forecasts }\end{array}$ & Yes & \\
\hline February 9, 2001 & $\begin{array}{l}\text { Introduced "Lombard-type" facility; reduced } \\
\text { discount rate to } 0.35 \%\end{array}$ & Yes & Yes \\
\hline $\begin{array}{l}\text { February 28, } \\
2001\end{array}$ & $\begin{array}{l}\text { Reduced call rate to } 0.15 \% \text {; reduced discount } \\
\text { rate to } 0.25 \% \text { next day }\end{array}$ & Yes & \\
\hline March 19, 2001 & $\begin{array}{l}\text { Changed main operating target to outstanding } \\
\text { balance of current accounts at the BOJ instead } \\
\text { of call rate; Stated that "The new procedure } \\
\text { will be kept in place until the CPI registers a } \\
\text { stable zero percent or increase year-on- } \\
\text { year" c }\end{array}$ & $\begin{array}{l}\text { No: "The Bank } \\
\text { still has no } \\
\text { intentions to } \\
\text { increase the } \\
\text { amount of } \\
\text { outright purchase } \\
\text { of long-term } \\
\text { government } \\
\text { bonds..."d }\end{array}$ & \\
\hline May 18, 2001 & $\begin{array}{l}\text { Extended the maturity date for bills purchased } \\
\text { from } 3 \text { to } 6 \text { months }\end{array}$ & & Yes \\
\hline August 14, 2001 & $\begin{array}{l}\text { Increased guideline for money market } \\
\text { operations from } 5 \text { to } 6 \text { trillion yen; increased }\end{array}$ & Yes & \\
\hline
\end{tabular}




\begin{tabular}{|c|c|c|c|}
\hline Date & Development & $\begin{array}{l}\text { Change stance? } \\
\text { (Quantity/Rate) }\end{array}$ & $\begin{array}{l}\text { Change assets } \\
\text { purchased? }\end{array}$ \\
\hline & $\begin{array}{l}\text { outright purchase of long-term government } \\
\text { bonds from } 400 \text { billion to } 600 \text { billion yen per } \\
\text { month }\end{array}$ & & \\
\hline $\begin{array}{l}\text { September 18, } \\
2001\end{array}$ & Reduced discount rate to $0.10 \%$ & Yes & \\
\hline $\begin{array}{l}\text { December 19, } \\
2001\end{array}$ & $\begin{array}{l}\text { Increased target outstanding balance of current } \\
\text { accounts to a 10-15 trillion yen range; } \\
\text { increased outright purchase of long-term } \\
\text { government bonds from } 600 \text { billion to } 800 \\
\text { billion yen per month }\end{array}$ & Yes & Yes \\
\hline January 16,2002 & $\begin{array}{l}\text { Enhanced CP repos including extension to } \\
\text { asset-backed CP; expanded range of } \\
\text { government bonds to be purchased or sold }\end{array}$ & & Yes \\
\hline $\begin{array}{l}\text { February 28, } \\
2002\end{array}$ & $\begin{array}{l}\text { Increased guideline for liquidity provision to } \\
\text { market beyond CAB target; increased outright } \\
\text { purchase of long-term government bonds to } 1 \\
\text { trillion yen per month }\end{array}$ & Yes & Yes \\
\hline March 20, 2002 & $\begin{array}{l}\text { Expanded range of eligible collateral for repos } \\
\text { to include mortgage-backed securities and } \\
\text { loans to the government and DIC }\end{array}$ & & Yes \\
\hline $\begin{array}{l}\text { September } 18 \text {, } \\
2002\end{array}$ & $\begin{array}{l}\text { Introduced operations in "outright purchase of } \\
\text { (government) bills"; offered to buy up to } 2 \\
\text { trillion yen in equities held by the banking } \\
\text { system }\end{array}$ & & Yes \\
\hline October 30, 2002 & $\begin{array}{l}\text { Increased } \mathrm{CAB} \text { target to } 15-20 \text { trillion yen; } \\
\text { increased outright purchases of government } \\
\text { bonds to } 1.2 \text { trillion yen per month }\end{array}$ & Yes & \\
\hline $\begin{array}{l}\text { December } 17, \\
2002\end{array}$ & $\begin{array}{l}\text { Relaxed standards on collateral from deeds } \\
\text { and ABCP }\end{array}$ & & Yes \\
\hline
\end{tabular}

Notes: (a) It was on this date that the BOJ initiated the Zero Interest Rate Policy, which was set-up based on a new guideline for money market operations: "The Bank of Japan will provide more ample funds and encourage the uncollateralized overnight call rate to move as low as possible." (b) For details, see http://www.boj.or.jp/en/seisaku/99/pb/g990409.htm. (c) See http://www.boj.or.jp/en/seisaku/01/pb/k010319b.htm. (d) See http://www.boj.or.jp/en/seisaku/01/pb/k010319c.htm. 
Figure 1

Alternative Estimates of the Output Gap for Japan

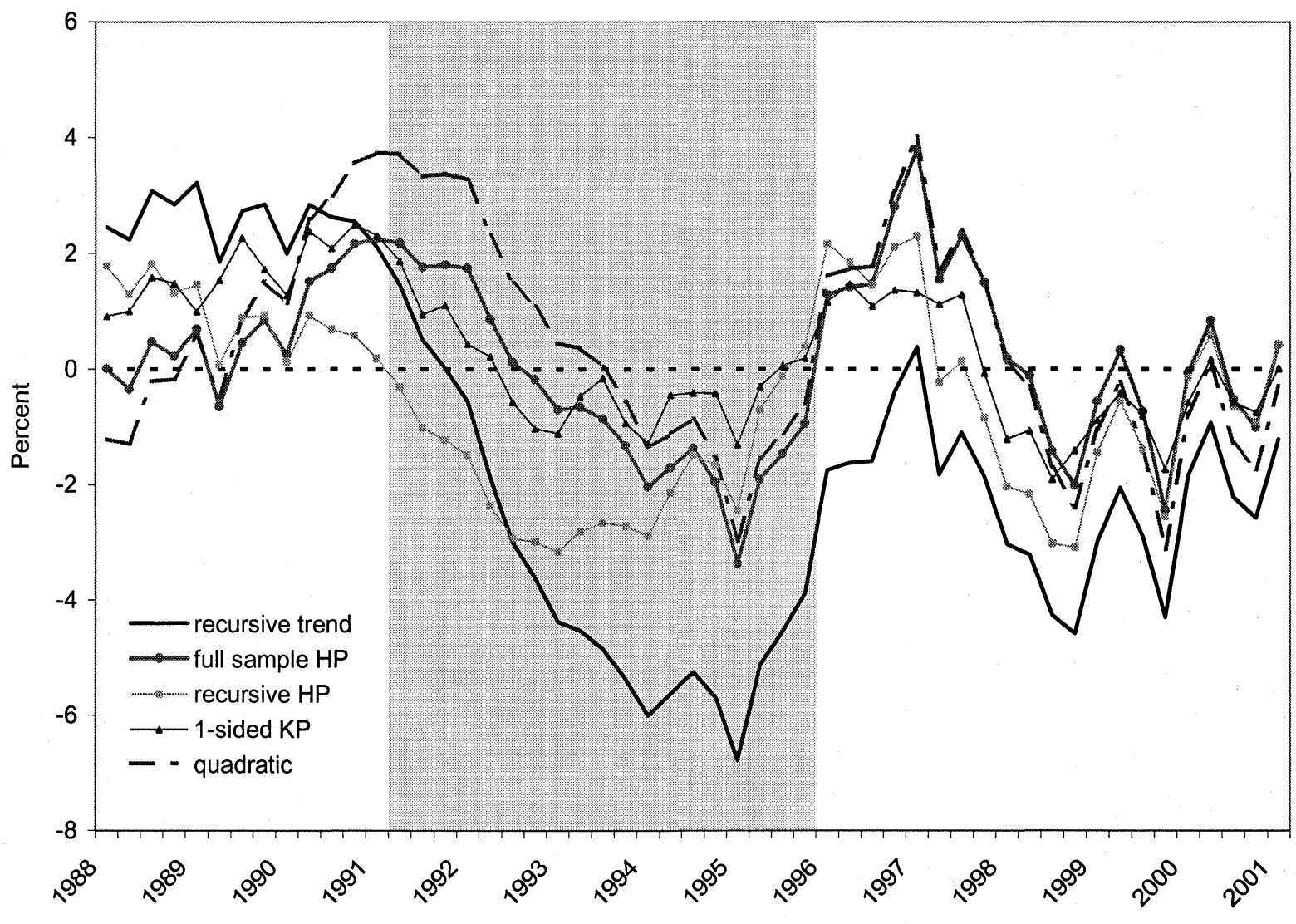


Figure 2

Alternative Estimates of Trend Growth in Japan

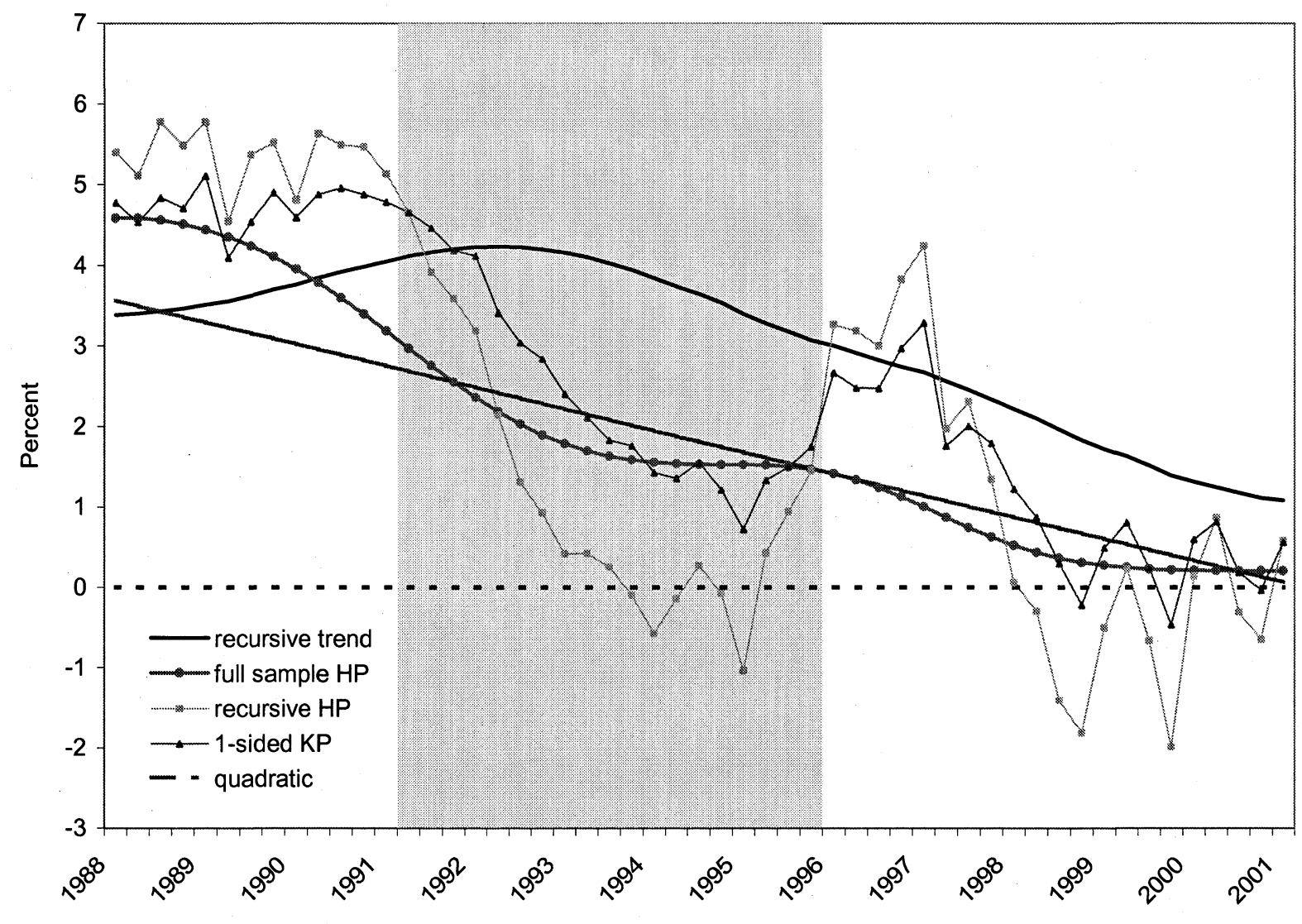




\section{Figure 3}

Call Money Rate and Rate Implied by Calibrated Taylor Rule
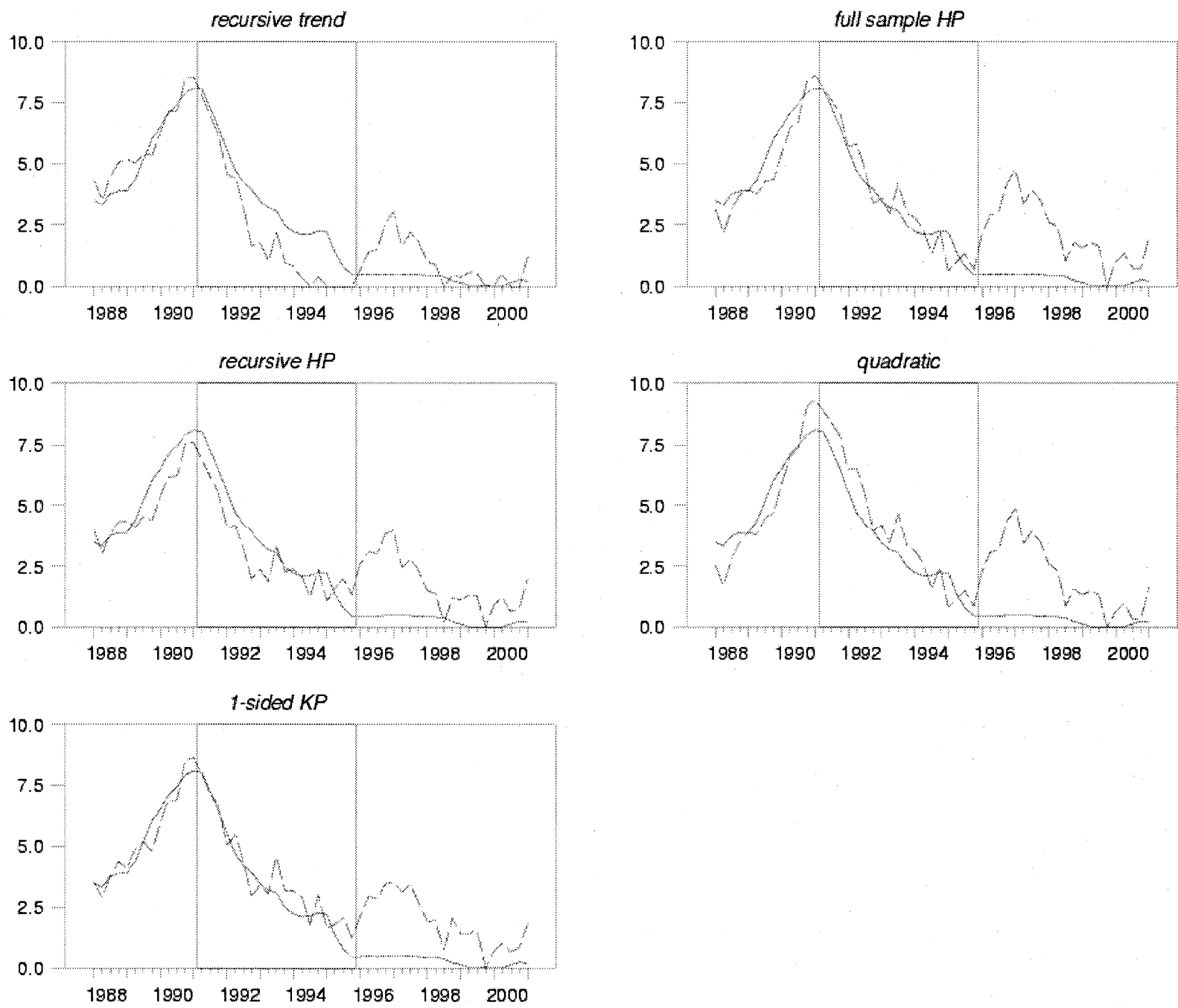

Notes: The reaction function used is $\tilde{t}_{t}=5+1.5 \times\left(\pi_{t}-2\right)+0.5 \times\left(y_{t}-y_{t}^{*}\right)$, where $\pi_{t}$ is the four-quarter CPI inflation rate (adjusted for changes in the consumption tax), and $y_{t}-y_{t}^{*}$ is an estimate of the output gap. All variables are measured in percentage terms. 


\section{Figure 4}

\section{Call Money Rate and Rate Implied by Calibrated Clarida-Galí-Gertler Rule}
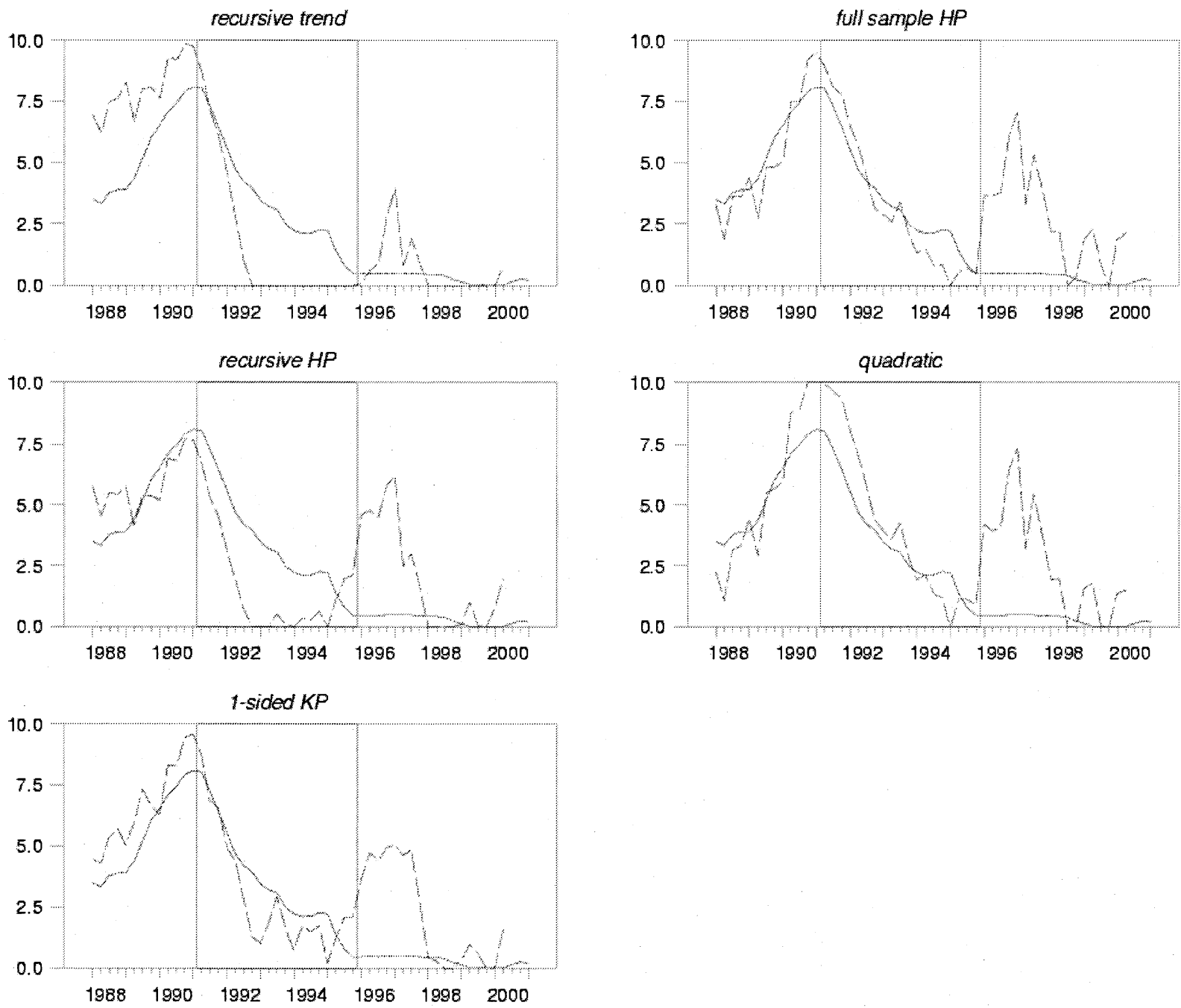

Notes: The reaction function used is $\tilde{t}_{t}=i_{0}+\beta \pi_{t}^{e}+\alpha\left(y_{t}-y_{t}^{*}\right)$, where $y_{t}-y_{t}^{*}$ is an estimate of the output gap, and $\pi_{t}^{e}$ is a forecast of the four-quarter CPI inflation rate (adjusted for changes in the consumption tax) based on two lags of inflation and the same estimate of the output gap. The parameter values chosen correspond to the baseline Volcker-Greenspan estimates in Clarida et al. (2000): $\beta=2.15$ and $\alpha=0.93$. All variables are measured in percentage terms. 
Figure 5

“Deflation Scares," 1992-2002

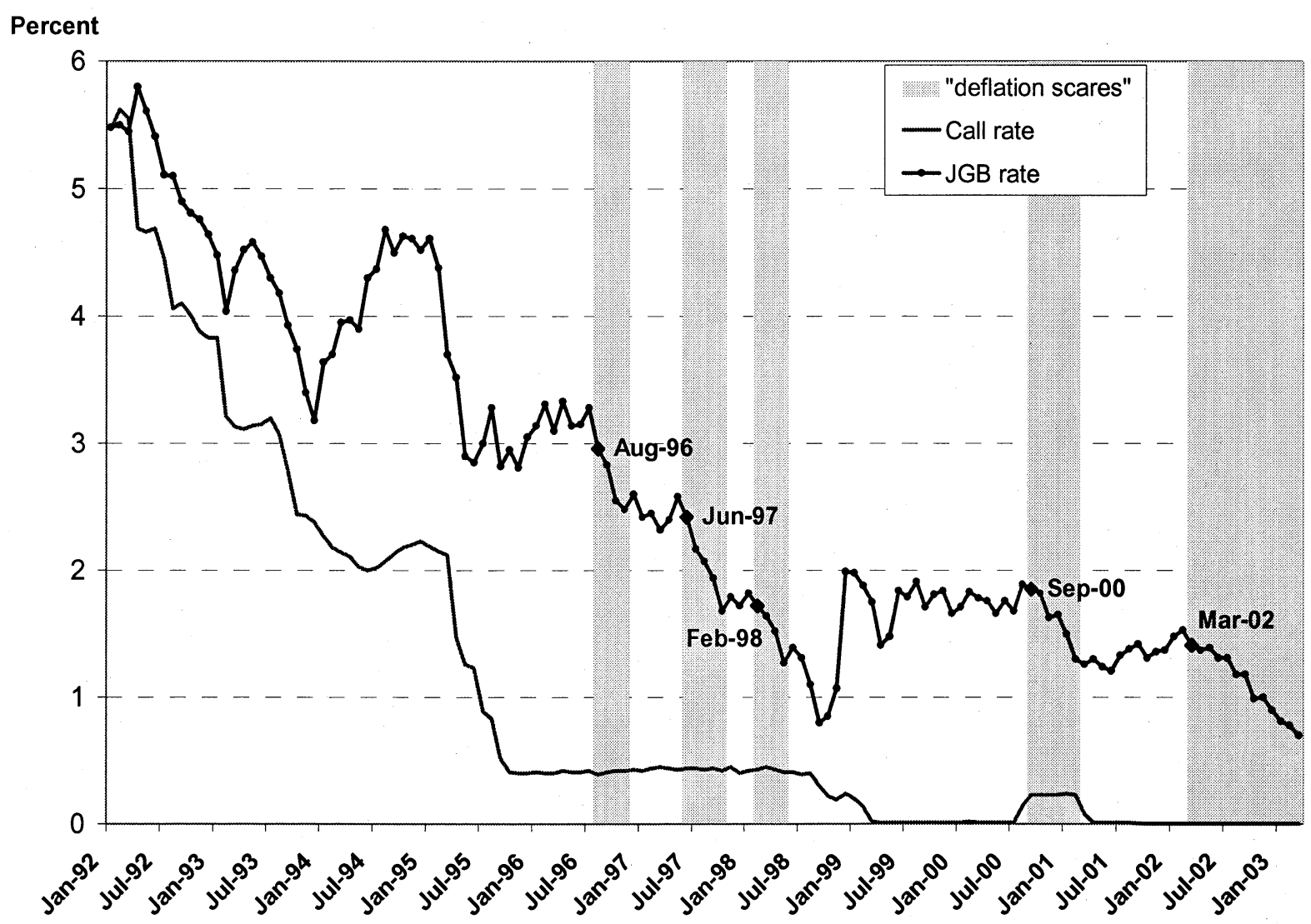

